\title{
Meningkatkan Hasil Belajar Operasi Hitung Perkalian Menggunakan Metode Permainan Kartu Bilangan Pada Siswa Kelas III SD Negeri Pabelan 2
}

\author{
Yusuf Udayana \\ SD Negeri Pabelan 2 \\ yusufudayana11@gmail.com
}

\section{Article History}

received 3/12/2020

revised 17/12/2020

accepted 31/12/2020

\begin{abstract}
Class action research was motivated by the discovery of cases of third grade students at SD Negeri Pabelan 2, it was identified that in learning mathematics, multiplication arithmetic operations were still low. This fact is shown through the value of the Minimum Completeness Criteria (KKM) for Mathematics, which is 75 , only $36 \%$ of students achieve the KKM score. The purpose of the research is to improve the achievement of mathematics learning outcomes with the number card game method. This study used a classroom action research design consisting of two cycles. Data collection techniques in this study through written tests and observations. From the results of the study showed that the mastery of learning increased in the first cycle by $68 \%$ and in the second cycle by $72 \%$. From these results it can be concluded that by applying the number card game method, multiplication and division counting operations material can improve mathematics learning outcomes and provide a fun learning atmosphere and can motivate students to be active in learning.
\end{abstract}

Keywords: learning outcomes, numbers, methods, number cards

\begin{abstract}
Abstrak
Penelitian tindakan kelas dilatarbelakangi adanya penemuan kasus siswa kelas III SD Negeri Pabelan 2, diidentifikasi bahwa dalam pembelajaran Matematika operasi hitung perkalian hasil belajarnya masih rendah. Fakta tersebut di tunjukkan melalui nilai Kriteria Ketuntasan Minimal ( KKM ) Matematika yaitu 75, hanya 36\% siswa yang mencapai nilai KKM tersebut. Tujuan diadakan penelitian adalah untuk Meningkatkan prestasi hasil belajar matematika dengan metode permainan kartu bilangan. Penelitian ini menggunakan rancangan penelitian tindakan kelas yang terdiri atas dua siklus. Teknik pengumpulan data dalam penelitian ini melalui tes tertulis dan observasi. Dari hasil penelitian menunjukkan bahwa ketuntasan belajar mengalami peningkatan pada siklus I sebesar $68 \%$ dan pada siklus II sebesar $72 \%$. Dari hasil tersebut dapat disimpulkan bahwa dengan menerapkan metode permainan kartu bilangan materi operasi hitung perkalian dan pembagian dapat meningkatkan hasil belajar matematika serta memberikan suasana belajar yang menyenangkan dan dapat memotivasi siswa untuk aktif dalam pembelajaran.
\end{abstract}

Kata kunci: hasil belajar, bilangan, metode, kartu bilangan

Social, Humanities, and Education Studies (SHEs): Conference Series https://jurnal.uns.ac.id/shes

p-ISSN 2620-9284

e-ISSN 2620-9292

This work is licensed under a Creative Commons Attribution-ShareAlike 4.0 International License. 


\section{PENDAHULUAN}

Dalam perkembangan pembelajaran pendidikan di Indonesia sering terjadi perubahan dalam hal materi maupun perangkat untuk pencapaian tujuan materi. Diantara perangkat-perangkat pencapaian tujuan tersebut strategi belajar mengajar memegang peranan yang penting dan menentukan di dalam pembelajaran, strategi belajar mengajar yang lainnya disebut dengan metode pengajaran, sangat menentukanmedia pembelajaran yang sesuai dengan karakteristik materi pembelajarannya sehingga pembelajaran itu tidak menarik bagi siswa.

Menurut The National for the Education of Young Children (dalam Yuliani 2007:30) menjelaskan bahwa: anak usia dini adalah anak yang berusia 0-8 tahun, sedangkan menurut undang-undang nomor 2003 anak usia dini adalah anak yang berada pada rentang usia 0-6 tahun.

Menurut Hurlock (dalam Tadkirotun, 2005: 2) bahwa : Bermain dapat diartikan sebagai kegiatan yang dilakukan demi kesenangan dan tanpa mempertimbangkan hasil akhir. Kegiatan tersebut dilakukan dengan cara suka rela, tanpa paksaan, atau tekanan dari pihak luar. Sedangkan menurut Triharso (2013:1) menyatakan bahwa : Bermain adalah suatu kegiatan yang dilakukan dengan atau tanpa mempergunakan alat yang menghasilkan informasi, memberikan kesenangan maupun mengembangkan imajinasi anak. Menurut pendapat ahli diatas dapat disimpulkan bahwa bermain merupakan sebuah kegiatan yang dilakukan dengan sengaja demi kesenangan dan meningkatkan kemampuan serta kecakapan anak dalam memecahkan suatu masalah dan memberikan kesenangan serta mengembangkan imajinasi anak.

Dalam menentukan metode pembelajaran juga harus memperhatikan karakteristik anak, sifatnya dan tahap perkembangannya. Menurut Kardi dalam Pitadjeng (2006: 24), sifat anak SD/MI dikelompokkan menjadi dua yaitu pada umur 69 tahun (anak SD tingkat rendah) dan pada umur 9-12 tahun (anak SD tingkat tinggi).

Matematika lebih menekankan kegiatan dalam dunia rasio (penalaran), bukan menekankan dari hasil eksperiman atau hasil observasi. Matematika terbentuk karena pikiran-pikiran manusia, yang berhubungan dengan ide, proses, dan penalaran Russefendi (Suwangsih, 2006:3)

Matematika merupakan suatu pelajaran yang tersusun secara beraturan, logis, berjenjang dari yang paling mudah hingga yang paling rumit. Dengan demikian, pelajaran matematika tersusun sedemikian rupa sehingga pengertian terdahulu lebih mendasari pengertian berikutnya. Beberapa pegertian matematika menurut para ahli yaitu :Menurut H.W. Fowler dalam Pandoyo (1997:1) matematika merupakan mata pelajaran yang bersifat abstrak, sehingga dituntut kemampuan guru untuk dapat mengupayakan metode yang tepat sesuai dengan tingkat perkembangan mental siswa.

Proses belajar yang baik dapat membangkitkan kegiatan belajar yang efektif, bermakna, dan menyenangkan(Pitadjeng, 2006: 82). Dalam kegiatan belajar di kelaslll SD Negeri Pabelan 2 semester I Kecamatan Mungkid Kabupaten Magelang, khususnya pembelajaran operasi hitung perkalian, belum terdapatproses pembelajaran yang dikatakan sebagai proses belajar yang baik. Hasil nilai rata-rata kelas tes formatif prasiklus mata pelajaran Matematika materi perkalian adalah nilai 61. Ini menunjukkan bahwa sebagian besar siswa hasil belajarnya rata - rata berada di bawah angka 65 atau di bawah KKM.

Dari latar belakang $\mathrm{di}$ atas, penulis dapat mengidentifikasi berbagai permasalahan sebagai berikut: 1) Rendahnya partisipasi dan respon siswa terhadap pembelajaran yang berlangsung. 2) Rendahnya tanggungjawab dan motivasi belajar siswa dalam setiap menyelesaikan tugas, baik yang dalam bentuk evaluasi maupun beban tugas tambahan di rumah. 3) Rendahnya hasil belajar siswa terhadap operasi hitung perkalian bilangan bulat. 4) Beberapa siswa gaduh sendiri, karena belum jelas maupun bermain-main sendiri. 
Dari hasil identifikasi guru bersama supervisor 2 dan teman sejawat menemukan berbagai permasalahan yang ada yang harus segera dianalisis yaitu: 1) Guru kurang memperhatikan pentingnya media dan penggunaan metode yang bervariatif. 2) Guru dalam pembelajaran cenderung melakukan pendekatan yang otoriter. 3) Guru kurang dalam membuat perencanaan pembelajaran yang baik sehingga kegagalan dalam pembelajaran diawal tidak dijadikan sebagai bahan kajian untuk memperbaiki pembelajaran berikutnya.

Berdasarkan identifikasi dan analisis masalah penulis merumuskan masalah sebagai berikut: 1) Bagaimanakah proses pembelajaran matematika materi perkalian dengan menggunakan metode kartu bilangan pada siswa kelas III Semester 1 Sekolah Dasar Negeri Pabelan 2 Kecamatan Mungkid Kabupaten Magelang Tahun Pelajaran 2018/2019?. 2) Bagaimana hasil peningkatan prestasi menghitung perkalian dengan metode kartu bilangan pada siswa kelas III Semester 1 Sekolah Dasar Negeri Pabelan 2 Kecamatan Mungkid Kabupaten Magelang Tahun Pelajaran 2018/2019?.

Berdasarkan rumusan masalah di atas, tujuan penelitian dapat dituliskan sebagai berikut: 1) Untuk mengetahui proses pembelajaran matematika materi perkalian siswa kelas III Semester 1 Sekolah Dasar Negeri Pabelan 2 Kecamatan Mungkid Kabupaten Magelang Tahun Pelajaran 2018/2019 dengan metode permainan kartu bilangan. 2) Meningkatkan prestasi hasil belajar matematika siswa kelas III Semester 1 Sekolah Dasar Negeri Pabelan 2 Kecamatan Mungkid Kabupaten Magelang Tahun Pelajaran 2018/2019 dengan metode permainan kartu bilangan.

\section{METODE}

Metode Permainan Kartu adalah cara mengajar yang dilaksanakan dalam bentuk permainan kartu. Permainan dilakukan dalam kelompok kecil yang beranggotakan 4-6 anak. Dalam permainan kartu bilangan, kartu dibagi habis kepada semua anggota, sisakan satu untuk memulai permainan, siswa mencari pasangan kartu yang terbuka, yang mempunyai pasangan kartu meletakkan kartu berikutnya untuk melanjutkan permainan. Dilakukan berulang sampai ada salah satu siswa yang kehabisan kartu dan dinyatakan sebagai pemenang.

Subjek Penelitian adalah siswa dan guru kelas III, dimana siswa berjumlah 25 orang; 14 siswa laki-laki dan 11 orang siswa perempuan. Berumur rata-rata antara 8-9 tahun. Penelitian ini dilaksanakan di SD Negeri Pabelan 2 yang beralamat di Jalan Pondok Pesantren Pabelan, Kalangan, Pabelan, Mungkid, kode pos 56551 Kecamatan Mungkid Kabupaten Magelang. Waktu Penelitian ini dilaksanakan pada bulan Oktober 2018, dimulai dari pra siklus, siklus I dan siklus II dengan rincian sebagai berikut.

Teknik analisis data yang digunakan untuk mengolah data tersebut adalah: 1) Analisis Kualitatif : Teknik analisis data ini terdiri dari tiga alur kegiatan yang berlangsung secara bersamaan yaitu reduksi data, penyajian data, dan penarikan kesimpulan atau verifikasi. 2) Analisis Kuantitatif : Hasil tes siswa dianalisis secara deskriptif kuantitatif. Pada setiap penilaian dihitung nilai rata-ratanya.

\section{HASIL DAN PEMBAHASAN}

Berdasarkan pelaksanaan proses pembelajaran pada tahap pra siklus, nilai rata - rata siswa masih di bawah 65 yang merupakan Kriteria Ketuntasan Minimal. Nilai rata - rata siswa pada tahap pra siklus ini adalah 63,6 . Berikut ini merupakan data nilai pada tahap pra siklus.

Berdasarkan hasil tes awal pada tabel di atas tergambar bahwa dari 25 siswa kelas III SD Negeri Pabelan 2 yang mengikuti tes, 16 siswa belum mencapai batas ketuntasan yaitu nilai 65 . Sedangkan yang telah mencapai batas tuntas yaitu memperoleh nilai 65 sebanyak 9 siswa.

Berdasarkan tabel dapat diketahui juga, nilai rata-rata siswa pada tes awal adalah sebesar 68,2 dengan persentase ketuntasan belajar 36\%. Dengan hasil tes 
awal itu, peneliti memutuskan untuk mengadakan penelitian pada materi pecahan sederhana dengan menggunakan metode pembelajaran pemecahan masalah (Problem Solving) untuk meningkatkan prestasi siswa. Pada meteri ini peneliti menetapkan KKM (kriteria ketuntasan minimal) $\geq 65$ dengan tujuan untuk mengetahui perbedaan sebelum diadakan penerapan pembelajaran menggunakan metode pembelajaran pemecahan masalah (Problem Solving) dan sesudah diadakan penerapan menggunakan metode pembelajaran pemecahan masalah (Problem Solving) ini.

Observasi Keterlaksanaan Pembelajaran. Pada siklus I kegiatan pembelajaran dengan metode Permainan Kartu Bilangan guru memberikan kebebasan kepada siswa untuk memilih anggota kelompoknya sendiri sehingga suasana kelas menjadi ramai. Persentase keterlaksanaan pembelajaran dengan metode Permainan Kartu Bilangan rata-rata mencapai $68 \%$ dengan kategori baik pada siklus I. Pada siklus II, persentase keterlaksanaan pembelajaran yang diperoleh rata-rata yaitu $72 \%$ dengan kategori baik sekali. Jadi dapat disimpulkan bahwa langkah-langkah pembelajaran sudah dilaksanakan dengan baik dan runtut sehingga persentasenya meningkat.

Sebelum melakukan penelitian tindakan kelas tentang operasi hitung perkalian dan perkalian pada tahap siklus I, Peneliti menyusun rencana tindakan sebagai berikut: (1) menentukan waktu pelaksanaan, (2) menentukan materi sesuai dengan Kompetensi Dasar, (3) menyusun Rencana Pelaksanaan Pembelajaran (RPP) sesuai dengan indikator, (4) menyusun lembar kerja siswa dan soal evaluasi, (5) menyusun pedoman penilaian, (6) menyusun lembar observasi, (7) menyiapkan sumber belajar dan alat permainan kartu bilangan. Dapat diketahui bahwa dengan menggunakan metode pembelajaran pemecahan masalah (Problem Solving), hasil tes tertulis siklus 1 siswa yang belum tuntasadalah sebanyak 9 siswa, dan siswa yang tuntas belajar sebanyak 17 siswa .

Berdasarkan tabel dapat diketahui juga, nilai rata-rata siswa pada tes awal adalah sebesar 71,20 dengan persentase ketuntasan belajar $68 \%$. Hal ini menunjukkan adanya peningkatan hasil belajar siswa dari tahap tes awal ke soal tes siklus 1. Dan berdasarkan tabel di atas terlihat bahwa untuk jenis soal nomor 1 sampai 3 yang merupakan soal perkalian dengan hasil 1 angka hampir $100 \%$ siswa mampu menjawabnya. Dan untuk soal nomor 4 dan 5 merupakan perkalian dengan hasil 2 angka masih sekitar $40 \%$.

Persentase ketuntasan belajar pada siklus I yang hanya $68 \%$, menunjukkan bahwa persentase ketuntasan belajar siswa masih dibawah kriteria ketuntasan yang telah ditentukan, yaitu $75 \%$. Dengan demikian masih diperlukan siklus berikutnya untuk membuktikan bahwa metode pembelajaran pemecahan masalah (Problem Solving) di SD Negeri Pabelan 2.

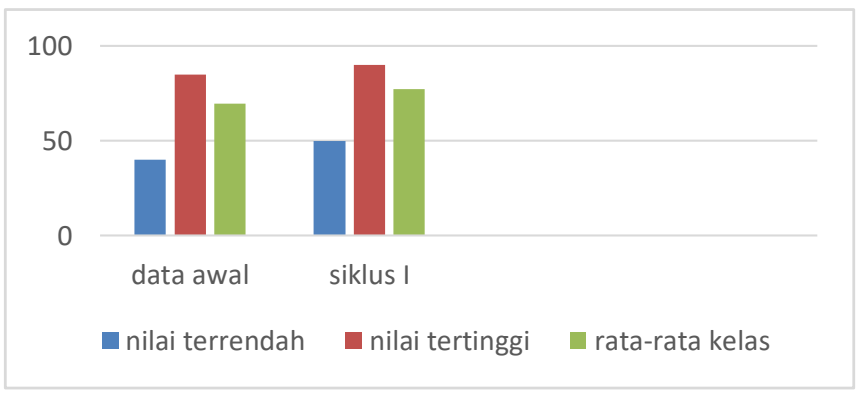

Gambar 1. Grafik Hasil Perkalian Siklus I

Data kondisi awal siswa kelas II sejumlah 25 siswa diperoleh dari pelaksanaan tes pra tindakan, diketahui bahwa nilai tertinggi 80 , nilai terendah 45 dan nilai rata-rata 
63,6. Siswa yang sudah tuntas sebanyak 9 siswa atau $36 \%$ dan yang belum tuntas sebanyak 16 siswa atau 64\%. Hasil pelaksanaan siklus pertama, nilai rata-rata meningkat menjadi 71,2 , sementara kriteria ketuntasan minimal juga meningkat menjadi $68 \%$. Peningkatan tersebut dikarenakan pembelajaran menjadi lebih efektif dalam suasana yang menyenangkan.

Peneliti menyusun rencana tindakan sebagai berikut: (1) menentukan waktu pelaksanaan, (2) menentukan materi sesuai dengan Kompetensi Dasar, (3) menyusun Rencana Pelaksanaan Pembelajaran (RPP) sesuai dengan indikator, (4) menyusun lembar kerja siswa dan soal evaluasi, (5) menyusun pedoman penilaian, (6) menyusun lembar observasi, dan (7) menyiapkan sumber belajar dan alat permainan kartu bilangan. Berdasarkan pengamatan peneliti pada siklus II ini, penggunaan metode permainan kartu bilangan cukup efektif, proses pembelajaran menjadi menyenangkan, siswa ikut berpartisipasi aktif dalam pembelajaran dan dapat meningkatkan kemampuan operasi hitung perkalian dan perkalian. Perbaikan dapat dilakukan dalam hal perkalian kelompok dengan tepat, penentuan permainan yang akan dilakukan harus disesuaikan dengan indikator, penyampaian aturan permainan diperjelas, manajemen waktu pelaksanaan dan kreatif guru dalam mengarahkan kegiatan pembelajaran dari awal sampai akhir agar sesuai dengan rencana yang telah dibuat.

\section{Peningkatan Hasil Perkalian}

100

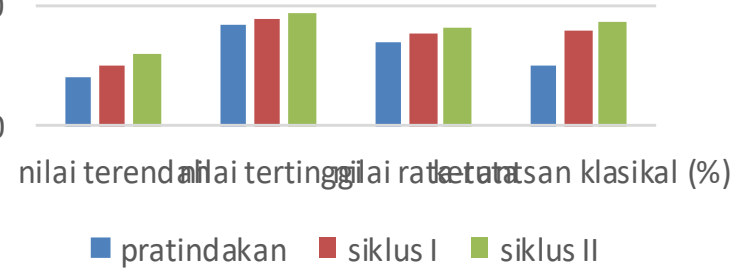

Gambar 2. Grafik peningkatan Perkalian dari pratindakan (kondisi awal, Siklus I, Siklus II)

Dari pelaksanaan tindakan siklus kedua, di dapat hasil yaitu terjadi peningkatan kemampuan operasi hitung perkalian dan perkalian siswa. Nilai rata-rata meningkat menjadi 78,4 , persentase pencapaian KKM menjadi $72 \%$ atau 18 siswa. Peningkatan terjadi karena proses belajar yang mudah dengan bermain. Dalam pembelajaran pada siklus kedua juga makin terlihat kalau pembelajaran berlangsung menyenangkan dengan menerapkan tiga prinsip utama pembelajaran yang disampaikan Jean Piaget (Achmad Sugandi dkk, 2004: 35) yaitu belajar aktif, belajar lewat interaksi sosial dan belajar lewat pengalaman sendiri. Siswa aktif dalam permainan, belajar lewat interaksi sosial dalam kelompok, dan semua dilakukan sendiri oleh siswa.

Dengan demikian kualitas pembelajaran Matematika melalui Metode Permainan Kartu Bilangan untuk operasi hitung perkalian dan perkaliandi kelas III SD Negeri Pabelan 2 Semester I Kecamatan Mungkid Kabupaten Magelang Tahun Pelajaran 2018/2019 dapat meningkat dan bisa dikatakan berhasil.

\section{SIMPULAN}

Berdasarkan hasil penelitian pada pembelajaran Matematika melalui metode permainan kartu bilangan tentang materi operasi hitung perkalian dapat disimpulkan hal-hal sebagai berikut: 1) Prestasi belajar Matematika materi perkalian meningkat. Dengan demikian penetapan hipotesis dalam penelitian ini benar atau dikatakan berhasil. 2) Penggunaan metode Permainan Kartu Bilangan dalam pembelajaran Matematika terbukti mampu meningkatkan kualitas proses pembelajaran mata 
pelajaran matematika operasi hitung perkalian di kelas III SD Negeri Pabelan 2 Kecamatan Mungkid Kabupaten Magelang semester 1 tahun pelajaran 2018/2019.

Berdasarkan hasil penelitian Metode Permainan Katu Bilangan dengan materi operasi hitung perkalian dalam pembelajaran, maka peneliti memberikan saran-saran sebagai berikut: 1) Guru hendaknya dapat menggunakan media kartu bilangan dalam pembelajaran di sekolah untuk meningkatkan motivasi, aktivitas, dan hasil belajar siswa pada mata pelajaran matematika materi operasi hitung perkalian. 2) Siswa hendaknya melakukan persiapan yang matang agar pelaksanaan pembelajaran dengan menggunakan media kartu bilangan berjalan efektif dan efisien, dalam memahami suatu konsep atau materi sehingga dapat meningkatkan hasil belajarnya. 3) Pembelajaran memerlukan berbagai variasi metode pembelajaran, alangkah baiknya jika kepala sekolah dapat melakukan pelatihan berbagai metode yang dapat di variasikan dalam pembelajaran. 4) Peneliti lain yang tertarik untuk melakukan penelitian dengan menggunakan metode permainan kartu bilangan, diharapkan dapat dijadikan acuan untuk melakukan penelitian lain pada pokok bahasan yang berbeda.

Di samping kedua hal tersebut, guru sebaiknya berkoordinasi dengan teman teman seprofesi dan pihak lain terkait guna memperkaya ilmu pengetahuan dan pengalaman.

\section{DAFTAR PUSTAKA}

Achmad Sugandi dkk. (2004). Teori Pembelajaran. Semarang: UPT MKK UNNES.

Andang Ismail. (2006). Education Games. Jakarta: Pilar Media.

Arikunto, Suharsimi. 2006. Prosedur Penelitian. Jakarta: PT. Rineka Cipta

Baharin Shamsudin. (2002). Kamus Matematika Bergambar. Jakarta: Grasindo

Dimyati dan Mudjiono. (2002). Belajar dan Pembelajaran. Jakarta: Depdikbud dan

Rineka Cipta. Pitajeng. 2006. Pembelajaran Matematika Yang Menyenangkan.

Departemen Pendidikan Nasional

Rusenffendi. (1988). Pengajaran Matematika Modern. Bandung: Transito.

Santrock, John W. (2007). Perkembangan Anak. Jakarta: Erlangga.

Sri Subarinah. (2006). Inovasi Pembelajaran Matematika Sekolah Dasar. Jakarta: Depdiknas.

Sudjana. (2010). Metode dan Teknik Pembelajaran Partisipatif. Bandung: Falah Production.

Sugiyono. (2009). Metode Penelitian Pendidikan. Bandung: Alfabeta

St. Negoro dan B. Harahap. (1998). Ensiklopedia Matematika. Jakarta: Ghalia Indonesia 